\title{
Creating a circular tower defense game: development and game experience measurement of orbital defense $X$
}

\author{
Auzi Asfarian ${ }^{* 1}$, Wiradani Ramadhan ${ }^{2}$, Widi Aryaguna Putra ${ }^{3}$, Gabriel Muhammad Raharjanto ${ }^{4}$, Rakish Frisky ${ }^{5}$ \\ Institut Pertanian Bogor, Indonesia 1,2,3,45
}

\section{Article Info}

Keywords:

Game Experience, User Experience, Tower

Defense, Game Development

\section{Article history:}

Received 10 March 2019

Revised 25 March 2019

Accepted 9 July 2019

Published 30 July 2019

\section{Cite:}

Asfarian, A., Ramadhan, W., Putra, W., Raharjanto, G., \& Frisky, R. (2019). Creating a Circular Tower Defense Game: Development and Game Experience Measurement of Orbital Defense X. Kinetik: Game Technology, Information System, Computer Network Computing, Electronics, and Control, 4(3). doi:http://dx.doi.org/10.22219/kinetik.v4i3.779

* Corresponding author.

Auzi Asfarian

E-mail address:

asfarian@apps.ipb.ac.id

\begin{abstract}
In this paper, we propose a new style of tower defense game by using the circular placement of the tower. In this game, dubbed Orbital Defense X, the player must protect the earth with a circle of defensive tower circled around it. The game is developed using game development lifecycle from initiation phase through alpha version. To test the quality of the developed game, we measure the game experience using game experience questionnaire. The questionnaire is divided into three: core, social presence, and post-game questionnaire. The results show that male participant gains a significantly higher score than female participants. Overall, the game experience is received better by the male participant in the core and social presence components, with an average score of 2,27 vs 1,92 and 2,15 vs 1,86 . However, in post-game experience, the female participant scores higher with 2,15 vs 1,95 . The participant that previously played another tower defense game gave score more in the core, social presence, and post-game experience than the participant that haven't played it before. Their score is 1,93 vs 2,37 in core, 1,67 vs 2,39 in social presence, and 2,07 vs 1,91 in post-game experience. The result also suggests for more attention in the challenge regarding the enemies (variety and difficulty) rather than more complex tower management system. The social ranking also suggested by the participant to improve the overall experience of this game.
\end{abstract}

\section{Introduction}

Tower defense game gained popularity in the past decade. After being popularized by Warcraft III, a variety of games in this genre emerged. Currently, there are more than 250 tower defense games available on Google Play and 457 games available on Steam. The examples of tower defense games are Kingdom Rush, Tiny Guardians, Plants vs Zombies, Plants vs Zombies Heroes, and Clash of Royale. This genre also popular in serious gaming like to improve mathematical skills [1] and introducing biological and health [2],[3].

Based on the definition by [4] and [5], the tower defense genre is characterized by (1) the player build defensive towers to obstruct the enemies (or creeps) from reaching the player's base, (2) the enemies come in waves with increased difficulties, (3) by defeating the enemies, the player will get resources corresponding to the difficulty of the enemy, that can be used to upgrade their towers, and (4) the tower can be bought, placed in the map, upgraded, and fire automatically on the enemy forces. As these only serve as a general characteristic, more gameplay and mechanic variation exist on the market.

General tower defense maps are typically in a rectangular shape with the player base located in the different side from the creeps spawning points. In this research, we aim to create a new model of tower defense by placing the player base in the center of the map. In this game, named Orbital Defense X, we adopt a model of planets in the solar system. Players have planets that must be protected by satellite-shaped towers arranged in orbit. Enemies come from various directions in the form of waves just like tower defense games in general.

In this study, we design and develop Orbital Defense X using game development lifecycle [6] until alpha version. Afterward, we measure the game experience using the game experience questionnaire [7],[8] and conducts an interview with alpha testers. Using the questionnaires data, we aim to gain insight and improvement direction of the proposed gameplay.

\section{Research Method}

\subsection{Game Development Process}

The Orbital Defense $X$ was developed from initiation until alpha version which refers to game development lifecycle guidelines [6] Figure 1. In the initiation phase, we conducted a brainstorming session to define the core-concept of the game. The game description generated from this session is: "This game depicts a war against an alien war machine that came to attack Earth. The player must defend the Earth by building upgradable orbital satellites circling 

and rotating around the planet. The alien will attack in waves until the player unable to protect the Earth. The achievement of this game will be the maximum score achievable by a player in a single playthrough."

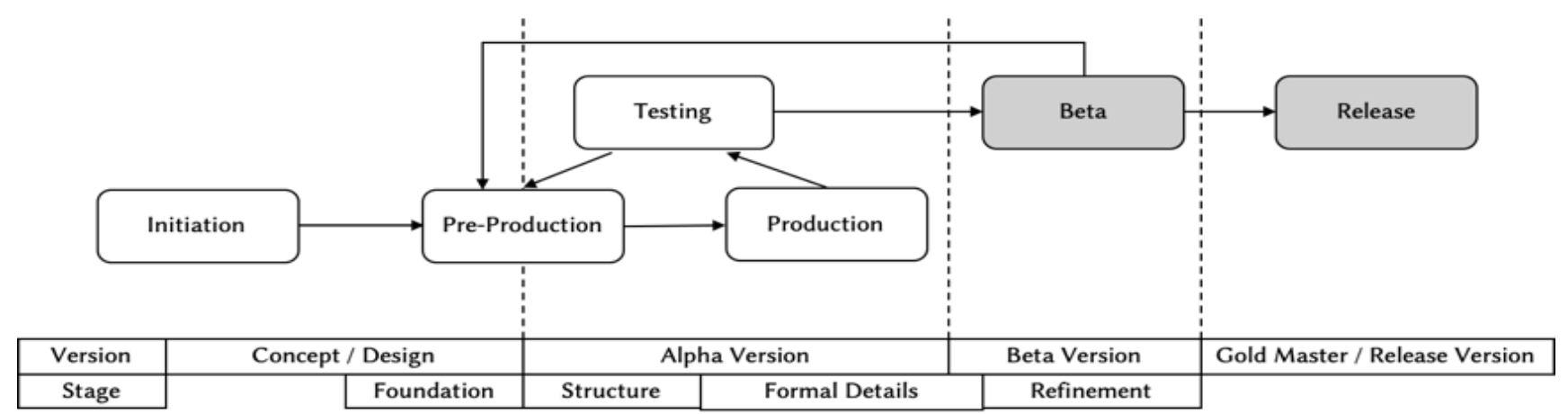

Figure 1. Game Development Lifecycle (GDLC) Proposed By [6]. In This Research, We Developed the Game from Concept into the Alpha Version.

On pre-production, we focused on game design and game prototype. In game design, we define the game genre, gameplay, mechanics, storyline, characters, challenges, fun factors, technical aspects, and its elements documentation in form of game design documents. The genre of the game is tower defense with a circular map as the gameplay. The mechanics include the defense tower type and its upgrade mechanic, power-ups, score calculation, and health. The storyline revolves around the Earth protection efforts from alien's invasion, with the player as the commander of Earth defense force. The challenge will be the type of enemy, their durability, and their number that will be increased as the game progresses and also in the tower management aspect. We aim the player can have fun in destroying a large number of enemies with power-ups or with their developed defense line to reach a higher score. The game will only use standard input and output available in a smartphone.

The next phase is creating the game prototype. The first prototype, called foundation, is created in form of a rough sketch Figure 2 to show the core gameplay and capabilities. The rough sketch then expanded into the second prototype, called structure, to show related core gameplay (the game control) and mechanics (arithmetic, logic, and game rules). For gameplay, the enemies will attack from all direction in waves. Every time the player success to survive a wave, a stronger wave will attack after a short break. To defeats the wave, the player must aim the tower by touching the intended direction by hand. The core mechanics supporting this gameplay includes the Earth (as the avatar of the player), the defense towers, the power-ups, and the enemies. The initial design of the mechanics is then balanced in the next phase.

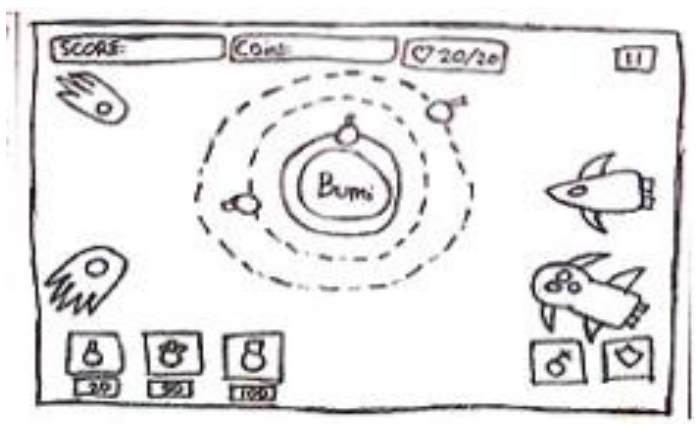

Figure 2. A Rough Sketch Depicts the Core Gameplay of Orbital Defense X. At First, We Named the Game Orbital-X, but Change It into Orbital Defense $X$ as Another Game with the Same Name, But Different Concept, Already

Released.

On the production phase, we implement the game design and mechanic into a playable game using Unity3D personal license. The visual assets are created from scratch while the audio assets are taken from non-copyrighted materials to make sure the game comply with copyright law. After the playable prototype created Figure 3, the initial mechanics are balanced using playtesting. The main driver of mechanic changes is the tower placement points that significantly less than standard tower defense game. The player might reach a strong defense system faster than we intended and the game challenge is diminished early. To prevent this, we increase the difficulties of tower management by making the tower destructible using hit points (HP) and fixed lifespan while removing the tower price inflation and tower building or upgrading time. The balanced mechanic on this phase is presented in Table 1. 
Table 1. The Core Mechanic of Orbital Defense $X$

Objects
Earth
The avatar of the players that must be protected from enemies attacks. In the
beginning, the player will have 20 life points. When enemies attack hit the
player, the life points will be decreased by 1.

Tower

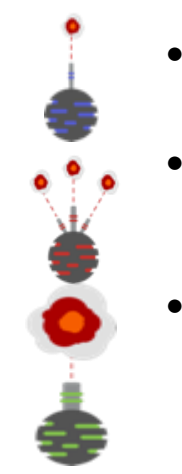

- Blue Tower: the basic tower designed to deals low damage to single enemies. When it collides with enemies it will decrease the tower HP by 1. Price: 5 coins, HP: 3 hits, damage: low, lifetime: $60 \mathrm{~s}$.

- Red Tower: more advanced tower designed to deals low damage to multiple enemies using a scattershot. When it collides with enemies it will decrease the tower HP by 1. Price: 10 coins, HP: 3 hits, damage: low, lifetime: $60 \mathrm{~s}$.

- Green Tower: more advanced tower designed to deals heavy damage to a single enemy using some a powered shoot with a limited area of effect. When it collides with enemies it will decrease the tower HP by 1. Price: 15 coins, HP: 3 hits, damage: high, lifetime: $60 \mathrm{~s}$.

Power-Up

A power-up can be used from the beginning of the game. The number of usages is unlimited, but it is restrained by the cooldown time.

- Bomb: when used, the bomb will instantly destroy all the enemies on the screen. Damage: instantly destroyed all the enemies in the screen, cooldown: $30 \mathrm{~s}$.

- Shield: when used, a protective field with its own hit points and lifespan will surround the player based and repel the enemy attacks. Shield HP: 3000 , lifetime: 10 seconds, cooldown: $30 \mathrm{~s}$.

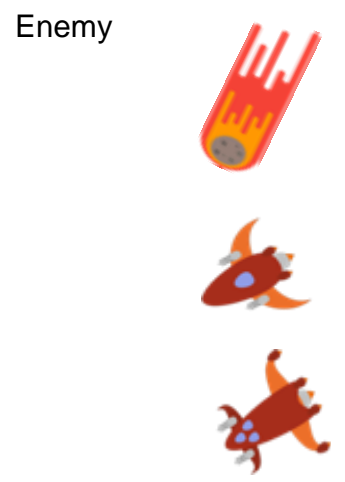

The object that must be destroyed by the player to prevent Earth destruction and gain resources to manage the defense towers. When the enemy attack collides with the earth, it will decrease 1 point from the player life

- Meteor: This kind of enemy designed as mere goon troops that can be destroyed with one shot from a low-damage tower. HP: low, coin drop: 1.

- Small enemies: This kind of enemy designed as a mid-boss that can be destroyed with multiple shots from a low-damage tower. HP: medium, coin drop: 1.

- Boss: This kind of enemy designed as higher difficulty enemies. When the boss appears, it is usually accompanied by the appearance of 2 small enemies. HP: high, coin drop: 1.

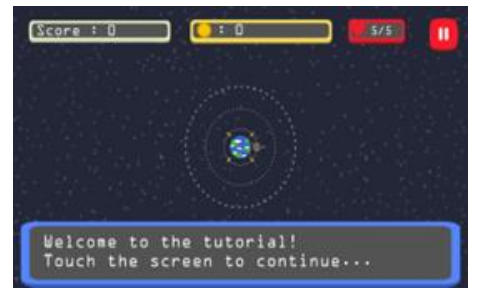

(a)

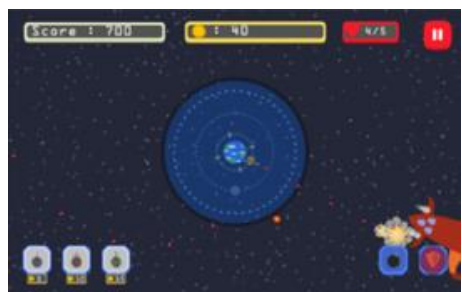

(b)

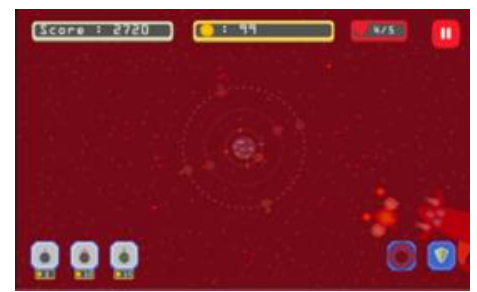

(c)

Figure 3. The Screenshots of the Playable Game. (a) is the Tutorial Screen, (b) is the Initial Screen, and (c) is the Scene When the Player Using the Bomb Power-ups to Obliterate Enemies.

Asfarian, A., Ramadhan, W., Putra, W., Raharjanto, G., \& Frisky, R. (2019). Creating a Circular Tower Defense Game: Development and Game Experience Measurement of Orbital Defense X. Kinetik: Game Technology, Information System, Computer Network, Computing, Electronics, and Control, 4(3). doi:http://dx.doi.org/10.22219/kinetik.v4i3.779 


\subsection{Game Experience Measurement}

\subsubsection{The Game Experience Questionnaire}

The Game Experience Questionnaire [7] consists of four set of questionnaires: the core module, the social presence module, the post-game module, and the in-game module. Each set different purposes and questions. The first three of the questionnaires are given to the tester immediately after they finished playing the game, while the ingame questionnaire is designed to be given between each playing session. Table 2 contains each questionnaire questions along with their Indonesia translation. Each question is answered with 0 (not at all) to 4 (extremely).

1. Core questionnaire (33 questions) is designed to capture seven component of game experience: competence, sensory and imaginative immersion, flow, tension/annoyance, challenge, negative effects, and positive effects.

2. Social Presence questionnaire (17 questions) investigate the relationship between the player with other social entities. This relation can be virtual (with in-game character), mediated (with other players), or co-located (playing in the same space). This questionnaire is not needed if the game doesn't involve social interaction. Seven components measured are psychological involvement-empathy, are psychological involvement-negative feeling, and behavioral involvement.

3. Post-Game questionnaire (17 questions) assess how the player feels after they stop playing. Four components measured by this questionnaire are positive experience, negative experience, tiredness, and returning to reality.

4. In-Game questionnaire (14 questions) is the simplified version of the core questionnaire that design for a multipleinterval testing session. The number of questions is fewer than the core questionnaire as only two questions per component added.

\subsubsection{Experiment Settings}

To measure the game experience from the Orbital Defense $X$, we asked 16 students in IPB University to play the game and fill in the questionnaire. The testing sessions are held in one batch and located in Multimedia Laboratory, Department of Computer Science, IPB University, Indonesia. Each session roughly has the following structure:

1. (10 minutes) Introduction, briefing, and preparation: the purpose of these steps is to make sure all participant understands the aims of the experiment. The game is introduced and the experiment structure and goals are explained to the participant. The participant then asked to install the Orbital Defense $\mathrm{X}$ and screen recording apps in their own devices. The pre-testing questionnaire is then administered. The questions include: gender, number of games played, average daily hours playing in smartphone/desktop, the favorite genre in smartphone/desktop, and the number of tower defense game played. If they played tower defense before, we asked them to rank the element of tower defense game in order of their preference.

2. (45 minutes) Playtesting: the playtesting is divided into three sessions. In each session, the participant will play the game until the game over. The score acquired by the participant is then noted. At the end of first two sessions, the participant is asked to fill in the in-game questionnaire.

3. (15 minutes) Questionnaire administration: after all playtesting session finished, the participant is then asked to fill in the core, social presence, and in-game questionnaire.

4. (15 minutes) Discussion and debrief: to supplement the questionnaire, we also conduct the discussion to explore insight from participant regarding the game experience.

Table 2. The Game Experience Questionnaire with Indonesian Translation

\begin{tabular}{|c|c|c|}
\hline No Category & English & Indonesian Translation \\
\hline \multicolumn{3}{|l|}{ A. Core Module } \\
\hline 1 Positive & I feel content & Saya merasa puas dan bahagia \\
\hline 2 Competence & I feel skillful & Saya merasa terampil \\
\hline 3 Immersion & $\begin{array}{l}\text { I was interested in the game's } \\
\text { story }\end{array}$ & Saya tertarik pada cerita permainan \\
\hline 4 Positive & I thought it was fun & Saya pikir permainan tadi menyenangkan \\
\hline 5 Flow & $\begin{array}{l}\text { I was fully occupied with the } \\
\text { game }\end{array}$ & Saya sepenuhnya sibuk dengan permainan \\
\hline 6 Positive & I felt happy & Saya merasa senang \\
\hline 7 Negative & It gave me a bad mood & Permainan ini memberi saya suasana hati \\
\hline 8 Negative & I thought about other things & Saya memikirkan hal yang lain \\
\hline 9 Negative & I found it tiresome & Saya merasa permainan ini melelahkan \\
\hline 10 Competence & I felt competent & Saya merasa kompeten \\
\hline 11 Challenge & I thought it was hard & Saya merasa permainan tadi sulit \\
\hline
\end{tabular}

(c) 2019 The Authors. Published by Universitas Muhammadiyah Malang

This is an open access article under the CC BY SA license. (https://creativecommons.org/licenses/by-sa/4.0/) 
Kinetik: Game Technology, Information System, Computer Network, Computing, Electronics, and Control

\begin{tabular}{|c|c|c|}
\hline 12 Immersion & It was aesthetically pleasing & Permainan ini secara estetis menyenangkan \\
\hline 13 Flow & I forgot everything around me & Saya melupakan segala yang ada di sekitar saya \\
\hline 14 Positive & I felt good & Saya merasa baik \\
\hline 15 Competence & I was good at it & Saya bagus dalam permainan ini \\
\hline 16 Negative & I felt bored & Saya merasa bosan \\
\hline 17 Competence & I felt successful & Saya merasa sukses \\
\hline 18 Immersion & I felt imaginative & Saya merasa imajinatif \\
\hline 19 Immersion & I felt that I could explore things & Saya merasa dapat menjelajahi berbagai hal \\
\hline 20 Positive & I enjoyed it & Saya menikmati permainan tadi \\
\hline 21 Competence & $\begin{array}{l}\text { I was fast at reaching the } \\
\text { game's targets }\end{array}$ & Saya cepat dalam mencapai target permainan \\
\hline 22 Tension & I felt annoyed & Saya merasa kesal \\
\hline 23 Challenge & I felt pressured & Saya merasa tertekan \\
\hline 24 Tension & I felt irritable & Saya merasa mudah tersinggung \\
\hline 25 Flow & I lost track of time & Saya sampai lupa akan waktu \\
\hline 26 Challenge & I felt challenged & Saya merasa tertantang \\
\hline 27 Immersion & I found it impressive & Saya menemukan permainan ini mengesankan \\
\hline 28 Flow & $\begin{array}{l}\text { I was deeply concentrated in } \\
\text { the game }\end{array}$ & Saya sangat berkonsentrasi dalam permainan \\
\hline 29 Tension & I felt frustrated & Saya merasa frustasi \\
\hline 30 Immersion & It felt like a rich experience & Saya merasa permainan ini kaya akan pengalaman \\
\hline 31 Flow & $\begin{array}{l}\text { I lost connection with the } \\
\text { outside world }\end{array}$ & Saya kehilangan koneksi dengan dunia luar \\
\hline 32 Challenge & I felt time pressure & Saya merasakan tekanan waktu \\
\hline 33 Challenge & I had to put a lot of effort into it & Saya harus berusaha keras untuk permainan ini \\
\hline \multicolumn{3}{|c|}{ B. In-Game Module } \\
\hline 1 Immersion & $\begin{array}{l}\text { I was interested in the game's } \\
\text { story }\end{array}$ & Saya tertarik pada cerita permainan \\
\hline 2 Competence & I felt successful & Saya merasa sukses \\
\hline 3 Negative & I felt bored & Saya merasa bosan \\
\hline 4 Immersion & I found it impressive & Saya merasa permainan ini sangat mengesankan \\
\hline 5 Flow & I forgot everything around me & Saya melupakan segala yang ada di sekitar saya \\
\hline 6 Tension & I felt frustrated & Saya merasa frustasi \\
\hline 7 Negative & I found it tiresome & Saya merasa permainan ini melelahkan \\
\hline 8 Tension & I felt irritable & Saya jadi merasa mudah tersinggung \\
\hline 9 Competence & I felt skillful & Saya merasa terampil dalam permainan ini \\
\hline 10 Flow & I felt completely absorbed & Saya merasa tenggelam dalam permainan \\
\hline 11 Positive & I felt content & Saya merasa puas dan bahagia \\
\hline 12 Challenge & I felt challenged & Saya merasa tertantang \\
\hline 13 Challenge & I had to put a lot of effort into it & Saya harus melakukan usaha yang lebih \\
\hline 14 Positive & I felt good & Saya merasa baik \\
\hline \multicolumn{3}{|c|}{ C. Social Presence Module } \\
\hline 1 Empathy & I empathize with the other(s) & Saya merasa berempati dengan orang lain \\
\hline 2 Involvement & $\begin{array}{l}\text { My actions depended on the } \\
\text { other(s) actions }\end{array}$ & Aksi yang saya lakukan bergantung pada aksi orang lain \\
\hline 3 Involvement & $\begin{array}{l}\text { The other's actions were } \\
\text { dependent on my actions }\end{array}$ & Aksi orang lain bergantung pada aksi yang saya lakukan \\
\hline
\end{tabular}


Kinetik: Game Technology, Information System, Computer Network, Computing, Electronics, and Control

\begin{tabular}{|c|c|c|}
\hline 4 Empathy & I felt connected to the other(s) & Saya merasa terhubung dengan orang lain \\
\hline 5 Involvement & $\begin{array}{l}\text { The other(s) paid close } \\
\text { attention to me }\end{array}$ & Orang lain menaruh perhatian khusus pada saya \\
\hline 6 Involvement & $\begin{array}{l}\text { I paid close attention to the } \\
\text { other(s) }\end{array}$ & Saya menaruh perhatian lebih kepada orang lain \\
\hline 7 Negative & I felt jealous about the other(s) & Saya merasa cemburu dengan orang lain \\
\hline 8 Empathy & $\begin{array}{l}\text { I found it enjoyable to be with } \\
\text { the other(s) }\end{array}$ & Saya merasa senang bersama orang lain \\
\hline 9 Empathy & $\begin{array}{l}\text { When I was happy, the } \\
\text { other(s) was(were) happy }\end{array}$ & Ketika saya senang orang lain ikut senang \\
\hline 10 Empathy & $\begin{array}{l}\text { When the other(s) was(were) } \\
\text { happy, I was happy }\end{array}$ & Ketika orang lain senang saya ikut merasa senang \\
\hline 11 Negative & $\begin{array}{l}\text { I influenced the mood of the } \\
\text { other(s) }\end{array}$ & Saya mempengaruhi suasana hati orang lain. \\
\hline 12 Negative & $\begin{array}{l}\text { I was influenced by the } \\
\text { other(s) moods }\end{array}$ & Saya dipengaruhi oleh suasana hati yang lain \\
\hline 13 Empathy & I admired the other(s) & Saya mengagumi orang lain \\
\hline 14 Involvement & $\begin{array}{l}\text { What the other(s) did affected } \\
\text { what I did }\end{array}$ & $\begin{array}{l}\text { Apa yang orang lain lakukan mempengaruhi apa yang } \\
\text { saya lakukan }\end{array}$ \\
\hline
\end{tabular}

C. Social Presence Module

\begin{tabular}{|c|c|c|}
\hline 15 Involvement & $\begin{array}{l}\text { What I did affected what the } \\
\text { other(s) did }\end{array}$ & $\begin{array}{l}\text { Apa yang saya lakukan mempengaruhi apa yang orang } \\
\text { lakukan }\end{array}$ \\
\hline 16 Negative & I felt revengeful & Saya merasa ingin balas dendam \\
\hline 17 Negative & $\begin{array}{l}\text { I felt schadenfreude (malicious } \\
\text { delight) }\end{array}$ & Saya merasa ingin berbuat iseng \\
\hline \multicolumn{3}{|c|}{ D. Post-Game Module } \\
\hline 1 Positive & I felt revived & Saya merasa terlahir kembali \\
\hline 2 Negative & I felt bad & Saya merasa bersalah \\
\hline 3 Reality & $\begin{array}{l}\text { I found it hard to get back to } \\
\text { reality }\end{array}$ & Saya merasakan sulit untuk kembali ke dunia nyata \\
\hline 4 Negative & I felt guilty & Saya merasa enak \\
\hline 5 Positive & It felt like a victory & Itu terasa seperti sebuah kemenangan \\
\hline 6 Negative & I found it a waste of time & Saya merasa ini hanya buang-buang waktu \\
\hline 7 Positive & I felt energized & Saya merasa bersemangat \\
\hline 8 Positive & I felt satisfied & Saya merasa puas \\
\hline 9 Reality & I felt disoriented & Saya merasa bingung \\
\hline 10 Tiredness & I felt exhausted & Saya merasa sangat lelah (fisik) \\
\hline 11 Negative & $\begin{array}{l}\text { I felt that I could have done } \\
\text { more useful things }\end{array}$ & $\begin{array}{l}\text { Saya rasa saya dapat melakukan hal lain yang lebih } \\
\text { bermanfaat }\end{array}$ \\
\hline 12 Positive & I felt powerful & Saya merasa kuat \\
\hline 13 Tiredness & I felt weary & Saya merasa lelah (emosional) \\
\hline 14 Negative & I felt regret & Saya merasa menyesal \\
\hline 15 Negative & I felt ashamed & Saya merasa malu \\
\hline 16 Positive & I felt proud & Saya merasa bangga \\
\hline 17 Reality & $\begin{array}{l}\text { I had a sense that I had } \\
\text { returned from a journey }\end{array}$ & $\begin{array}{l}\text { Saya memiliki perasaan ketika saya kembali dari sebuah } \\
\text { perjalanan }\end{array}$ \\
\hline
\end{tabular}

(c) 2019 The Authors. Published by Universitas Muhammadiyah Malang

This is an open access article under the CC BY SA license. (https://creativecommons.org/licenses/by-sa/4.0/) 


\section{Results and Discussion}

\subsection{Participants Demography}

Table 3, depicts the participant demography and previous experience with tower defense game. Five participants born in 1998, eight born in 1999, and three born in 2000. Four participants are female while the rest is male. The findings on [9] are consistent with this research as all the female participant haven't played tower defense game before, meanwhile only three from twelve male participants haven't. The participants show more tendency to play in their mobile devices ( 1.56 hours per day) than their laptop or desktop ( 1.44 hours per day). Three participants said that they are not playing in mobile devices, and two not playing in laptop.

In term of participant performance, Figure 4(a) shows that the top four score in the final session is held by the player that have previous experience with tower defense game (participant $6,10,11$, and 16) and playing more than 3 hours per day in both devices. Participant 15 scored fifth highest despite low playing time. In the debrief, it was revealed he once very active player but stop playing three years ago. Figure 4(b) shows that male participant performance is significantly higher than female participant while Figure 4(c) This is consistent with [9] that found that tower defense game is more popular in a male player base. It also shows that participant that played another tower defense game scored significantly higher than others.

The nine participant that already played another tower defense game before then asked to rank the common tower defense challenge according to their preferences Table 4. Based on the weighted rank, the participant given more preferences to the challenge related to the enemies than the tower itself. The tower management and variation aspect of the game ranked in the bottom.

Table 3. Participants Demography

\begin{tabular}{cccccccc}
\hline No & Gender & $\begin{array}{c}\text { Daily Hours } \\
\text { Playing } \\
\text { (Mobile) }\end{array}$ & $\begin{array}{c}\text { Favorite } \\
\text { Genre } \\
\text { (Mobile) }\end{array}$ & $\begin{array}{c}\text { Daily Hours } \\
\text { Playing } \\
\text { (Desktop) }\end{array}$ & $\begin{array}{c}\text { Favorite } \\
\text { Genre } \\
\text { (Desktop) }\end{array}$ & $\begin{array}{c}\text { Played } \\
\text { TD } \\
\text { Before? }\end{array}$ & $\begin{array}{c}\text { \#TD Game } \\
\text { Played }\end{array}$ \\
\hline \hline 1 & Female & 5 & Racing & 0 & Racing & No & 0 \\
2 & Male & 1 & Action & 1 & Action & Yes & $1-3$ \\
3 & Male & 2 & Adventure & 2 & Strategy & No & 0 \\
4 & Female & 1 & Strategy & 1 & Adventure & No & 0 \\
5 & Male & 0 & Sport & 2 & Adventure & No & 0 \\
6 & Male & 1 & Strategy & 2 & MMO & Yes & $4-5$ \\
7 & Female & 1 & Action & 1 & Strategy & No & 0 \\
8 & Male & 2 & MMO & 1 & Simulation & Yes & $1-3$ \\
9 & Male & 2 & RPG & 1 & RPG & Yes & $1-3$ \\
10 & Male & 2 & MMO & 1 & MMO & Yes & $1-3$ \\
11 & Male & 2 & RPG & 2 & Adventure & Yes & $1-3$ \\
12 & Female & 1 & Strategy & 1 & Sport & No & 0 \\
13 & Male & 0 & Adventure & 2 & MMO & Yes & $1-3$ \\
14 & Male & 3 & Strategy & 1 & Adventure & Yes & $1-3$ \\
15 & Male & 0 & RPG & 0 & RPG & No & 0 \\
16 & Male & 2 & RPG & 5 & Adventure & Yes & $1-3$ \\
\hline
\end{tabular}

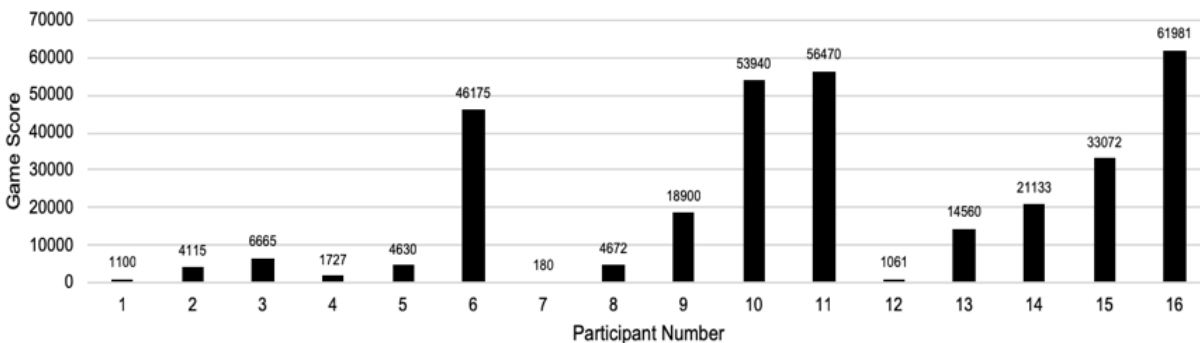

(a) Participants score in the third play

Asfarian, A., Ramadhan, W., Putra, W., Raharjanto, G., \& Frisky, R. (2019). Creating a Circular Tower Defense Game: Development and Game Experience Measurement of Orbital Defense X. Kinetik: Game Technology, Information System, Computer Network, Computing, Electronics, and Control, 4(3). doi:http://dx.doi.org/10.22219/kinetik.v4i3.779 


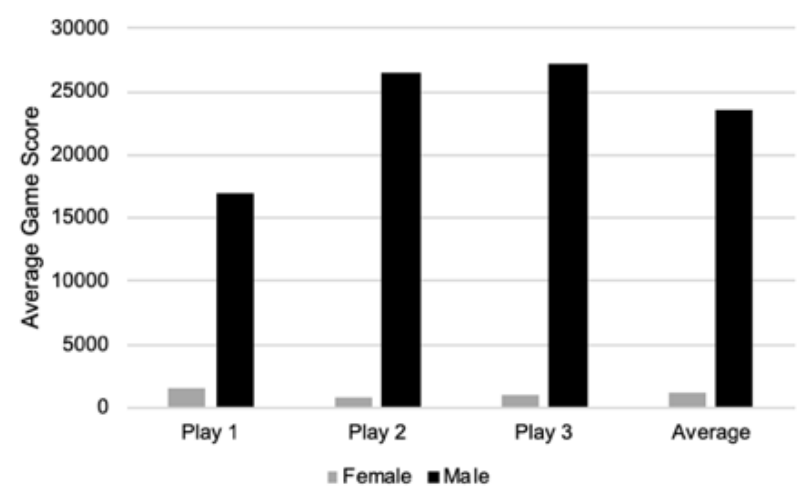

(b) Performance comparison between female and male participants.

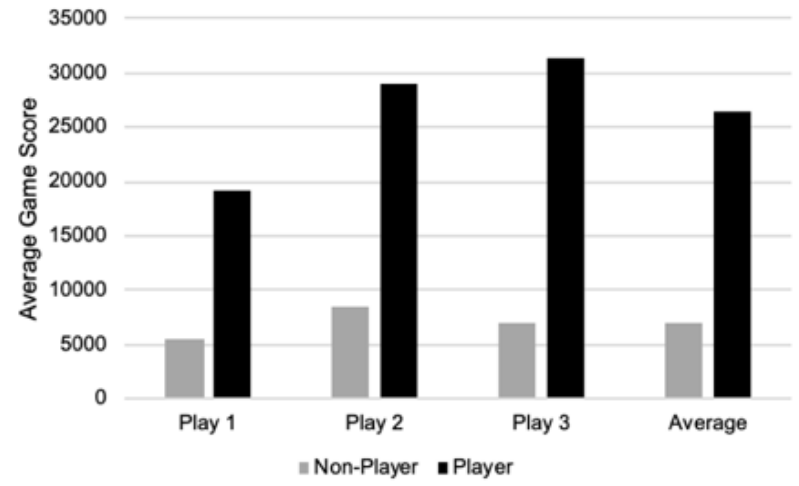

(c) Performance comparison between non-tower defense player vs players.

Figure 4. The Performance (Score) of the Participant When Playing Orbital Defense $X$

Table 4. Most Popular (1) To Most Unpopular (5) Challenge in Tower Defense Game According to Participants

\begin{tabular}{|c|c|c|c|c|c|c|c|}
\hline \multirow[t]{2}{*}{ No } & \multirow[t]{2}{*}{ Challenge } & \multicolumn{5}{|c|}{$\begin{array}{l}\text { Rank Frequencies } \\
(\mathrm{N}=9)\end{array}$} & \multirow{2}{*}{$\begin{array}{l}\text { Weighted } \\
\text { Rank }\end{array}$} \\
\hline & & 1 & 2 & 3 & 4 & 5 & \\
\hline 1 & Varied number of enemies & 2 & 2 & 4 & 1 & 0 & 2,4 \\
\hline 2 & Increased difficulty of enemy waves. & 2 & 3 & 2 & 1 & 1 & 2,6 \\
\hline 3 & Enemies that attacked in wave. & 2 & 2 & 2 & 1 & 2 & 2,9 \\
\hline 4 & Defense tower management (placement and upgrade) & 1 & 2 & 0 & 5 & 1 & 3,3 \\
\hline 5 & Variation of defense tower & 2 & 0 & 1 & 1 & 5 & 3,8 \\
\hline
\end{tabular}

\subsection{Questionnaires Analysis}

The results of the questionnaire are presented in Table 5 and Figure 5. Overall, the game experience is received better by male participant in core and social presence components, with an average score of 2,27 vs 1,92 and 2,15 vs 1,86. These scores is consistent in all components of core and social presence components Figure $5(a)$, Figure 5 (c). In the testing sessions, the male participant more likely to reveal their score to others and expressed their admiration or jealousy more if their score is lower than other. The male participant also tends to involve more with other in playing the game, showing the clear interest on how his friends playing the game and even asked for playing tips.

Table 5. The Questionnaires Average and Standard Deviation Results for Each Component

\begin{tabular}{|c|c|c|c|c|c|c|c|c|}
\hline & \multicolumn{2}{|c|}{ Female } & \multicolumn{2}{|c|}{ Male } & \multicolumn{2}{|c|}{ Non-Player } & \multicolumn{2}{|c|}{ Player } \\
\hline \multirow{2}{*}{$\overline{\text { Core }}$} & Avg. & \multirow[t]{2}{*}{ St. Dev. } & \multirow[t]{2}{*}{ Avg. } & \multirow[t]{2}{*}{ St. Dev. } & \multirow[t]{2}{*}{ Avg. } & \multirow[t]{2}{*}{ St. Dev. } & \multirow[t]{2}{*}{ Avg. } & \multirow[t]{2}{*}{ St. Dev. } \\
\hline & 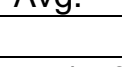 & & & & & & & \\
\hline Competence & 1,70 & 0,77 & 2,45 & 0,84 & 1,69 & 0,81 & 2,71 & 0,56 \\
\hline Immersion & 2,04 & 0,77 & 2,38 & 0,71 & 1,95 & 0,88 & 2,56 & 0,34 \\
\hline Flow & 1,80 & 0,67 & 2,13 & 0,62 & 1,86 & 0,58 & 2,20 & 0,62 \\
\hline Tension & 1,83 & 1,11 & 2,11 & 0,64 & 2,05 & 0,90 & 2,04 & 0,59 \\
\hline Challenge & 1,83 & 0,85 & 2,23 & 0,65 & 1,87 & 0,75 & 2,34 & 0,57 \\
\hline Negative & 2,06 & 0,63 & 2,29 & 0,82 & 2,00 & 0,80 & 2,42 & 0,66 \\
\hline Positive & 2,15 & 0,75 & 2,28 & 0,48 & 2,11 & 0,67 & 2,36 & 0,34 \\
\hline Overall & 1,92 & & 2,27 & & 1,93 & & 2,37 & \\
\hline \multicolumn{9}{|c|}{ Social Presence } \\
\hline Empathy & 1,75 & 1,08 & 2,07 & 0,81 & 1,45 & 0,93 & 2,41 & 0,53 \\
\hline Negative & 1,95 & 1,27 & 2,23 & 0,63 & 1,80 & 0,96 & 2,44 & 0,55 \\
\hline Involvement & 1,88 & 1,30 & 2,14 & 0,63 & 1,76 & 0,93 & 2,31 & 0,64 \\
\hline Overall & 1,86 & & 2,15 & & 1,67 & & 2,39 & \\
\hline
\end{tabular}

Post-Game

(C) 2019 The Authors. Published by Universitas Muhammadiyah Malang

This is an open access article under the CC BY SA license. (https://creativecommons.org/licenses/by-sa/4.0/) 
Kinetik: Game Technology, Information System, Computer Network, Computing, Electronics, and Control

\begin{tabular}{|c|c|c|c|c|c|c|c|c|}
\hline Positive & 2,08 & 1,19 & 2,26 & 1,01 & 1,81 & 1,30 & 2,54 & 0,66 \\
\hline Negative & 2,08 & 1,00 & 1,93 & 0,87 & 1,88 & 1,15 & 2,04 & 0,64 \\
\hline Tiredness & 2,25 & 0,87 & 1,67 & 0,91 & 1,93 & 1,06 & 1,72 & 0,83 \\
\hline Reality & 2,17 & 1,03 & 1,94 & 0,87 & 2,02 & 1,09 & 1,98 & 0,75 \\
\hline Overall & 2,15 & & 1,95 & & 1,91 & & 2,07 & \\
\hline
\end{tabular}

However, in post-game experience the female participant scores higher with 2,15 vs 1,95 . The male participant only score higher in positive experience after playing the game Figure 5(e). The biggest difference is in tiredness, where the male participant only scores 1,67 , Although generally the male participant playing longer as the consequences of their high shore Figure 4, they are more accustomed to playing mobile game in the long run and doesn't feel tired as easily to their female counterpart.

The participant that previously played another tower defense game (player) scored more in all three questionnaires Figure 5(b), Figure 5(d), and Figure 5(f) than they that just played tower defense game (non-player). Their score is 2,37 vs 1,93 in core, 2,39 vs 1,67 in social presence, and 2,07 vs 1,91 in post-game experience. The prior knowledge of the similar game mechanic already proved to have positive effects to performance of the players [10]. The opposite trends, although only slightly, happened across three components: tension, tiredness, and reality. The non-player experienced more tension as their more experienced peers scored higher and proceed more smoothly than them. The tiredness also can be explained by the same reason before, as the more experienced player already accustomed to long playing session and stress in the tower defense game.

The score for the game, however, is quite low with no questionnaire category score more than 3,0 out of 4,0. We investigate this in the debrief session after the playtesting session finished. The first problem is in the challenge given by the game. According to Table 4., the participant prefers more challenge in the enemy's elements. This challenge is not accommodated by Orbital Defense X. Although we already implement harder challenge as the wave progressed by providing more enemies, the durability and power of individual enemy is not changed. Furthermore, we only implemented three kind of enemies (meteor, small enemies, boss). Because of this, the participant found less challenge in the late-game wave. Social ranking also suggested by participant to improve the overall experience of this game. Although the absence of this feature in the alpha version encourage the participants to asking their peers score, the participant said that the process will be better if the score is publicly known through virtual scoreboard. The participant also said that the presence of such feature may might them playing more to reach the highest score.

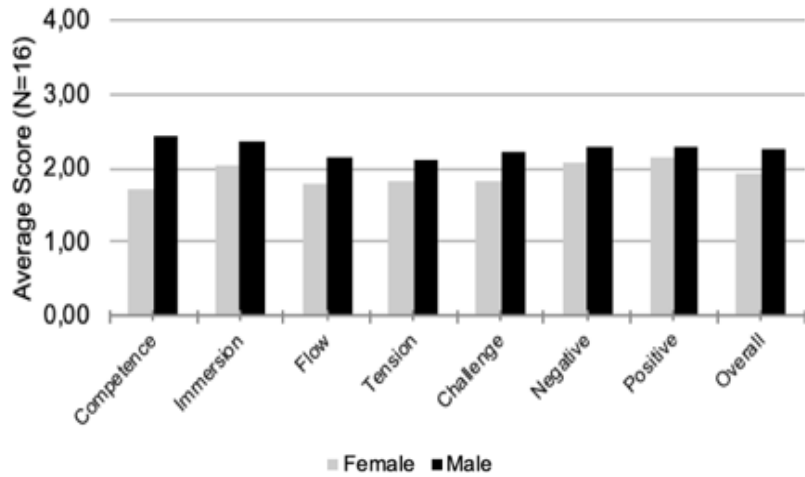

(a) Core questionnaire results (female vs male)

$$
4,00
$$

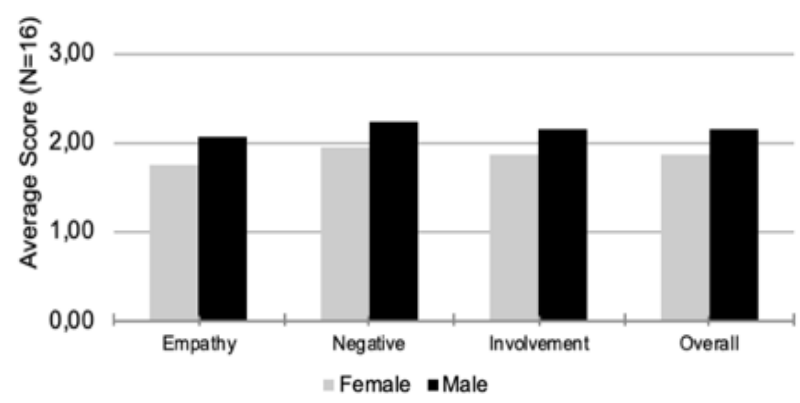

(c) Social presence questionnaire results (female vs male)

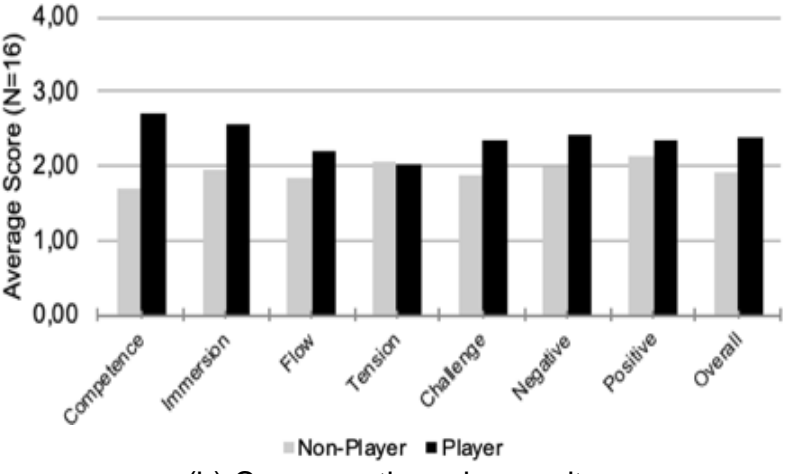

(b) Core questionnaire results (non-player vs player)

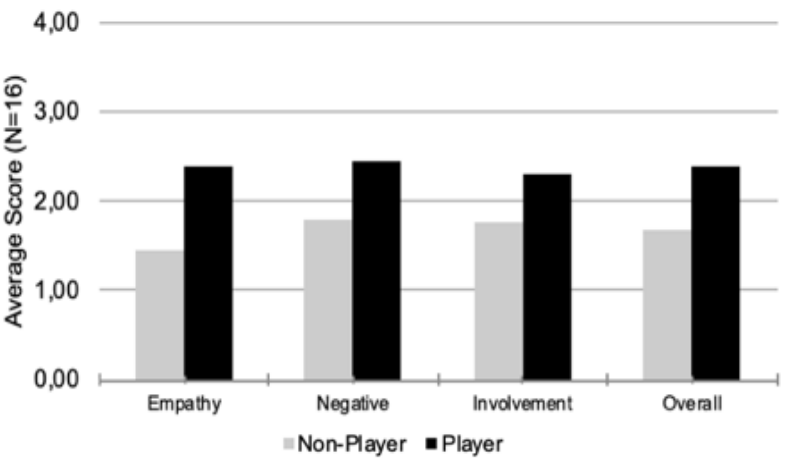

(d) Social presence questionnaire results (non-player vs player)

Asfarian, A., Ramadhan, W., Putra, W., Raharjanto, G., \& Frisky, R. (2019). Creating a Circular Tower Defense Game: Development and Game Experience Measurement of Orbital Defense X. Kinetik: Game Technology, Information System, Computer Network, Computing, Electronics, and Control, 4(3). doi:http://dx.doi.org/10.22219/kinetik.v4i3.779 


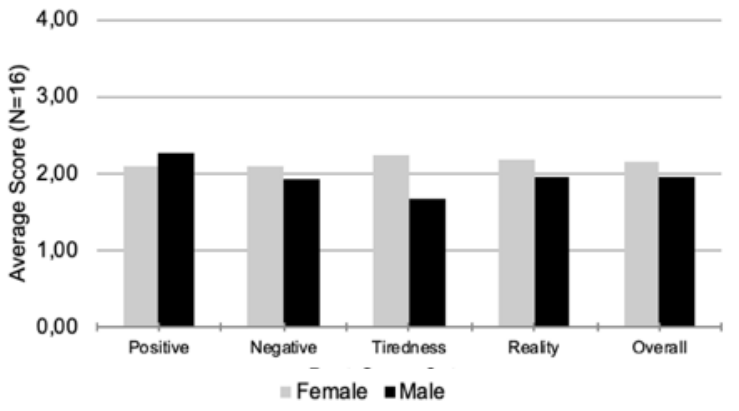

(e) Post-game questionnaire results (female vs male)

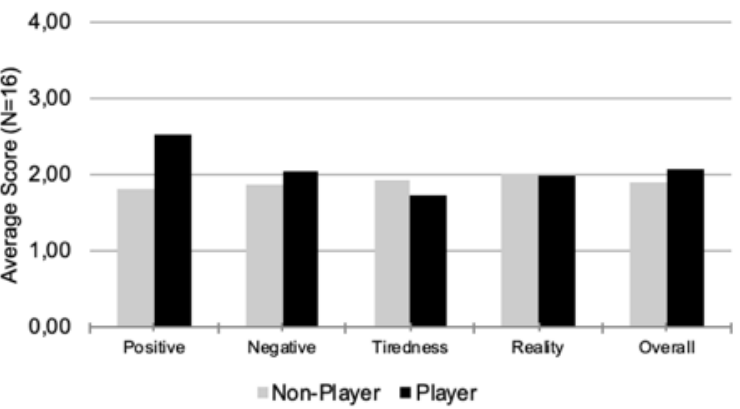

(f) Post-game questionnaire results (non-player vs player)

Figure 5. The Core, Social Presence, and Post-Game Questionnaire Average Value for Each Component, Contrasted by Non-Player Vs Player and Female Vs Male Participant

\section{Conclusion}

In this research, we have developed Orbital Defense $\mathrm{X}$, a circular tower defense game, until alpha version and measure how the game experienced by sixteen participants using the game experience questionnaire. Overall, the game experience is received better by male participant in core and social presence components, except in post-game experience. The participant that previously played another tower defense game gave score more in core, social presence, and post-game experience than the participant that haven't played It before. The overall score that less than three indicate that more improvement is needed before the game proceeds to the next phase (beta testing). The low scores are caused by the lack of challenge and variety in the game. The testers suggest for more attention in the challenge regarding the enemies (variety and difficulty) rather than more complex tower management system. Further improvement is needed to improve the overall response of players.

\section{References}

[1] A. Hernández-Sabaté, M. Joanpere, N. Gorgorió, and L. Albarracín. "Mathematics Learning Opportunities When Playing a Tower Defense Game," in International Journal of Serious Games, Vol. 2 No. 4, Pp. 57-71, 2015.

[2] J. Brich, K. Rogers, J. Frommel, M. Weidhaas, A. Bruckner, S. Mirabile, T. Dorn, V. Riemer, C. Schrader, M. Weber. "LiverDefense: Using A Tower Defense Game as A Customisable Research Tool," In 2015 7th International Conference on Games and Virtual Worlds for Serious Applications (VS-Games) - Proceedings, Pp. 1-8, 2015. https://doi.org/10.1109/VS-GAMES.2015.7295779

[3] E. Bassilious, A. DeChamplain, I. McCabe, M. Stephan, B. Kapralos, F. Mahmud, A. Dubrowski. "Power Defense: A Video Game for Improving Diabetes Numeracy," In 2011 IEEE International Games Innovation Conference (IGIC) - Proceedings, Pp. 124-125, 2011. https://doi.org/10.1109/IGIC.2011.6115113

[4] P. Avery, J. Togelius, E. Alistar, and R. P. Van Leeuwen. "Computational Intelligence and Tower Defence Games". In 2011 IEEE Congress of Evolutionary Computation (CEC) - Proceeding, Pp. 1084-1091, 2011. https://doi.org/10.1109/CEC.2011.5949738

[5] L.C. Leong, G. K. Soon, T. T. Guan, C. K. On, R. Alfred, and P. Anthony. "Self-synthesized Controllers for Tower Defense Game Using Genetic Programming," In 2013 IEEE International Conference on Control System, Computing and Engineering - Proceedings, Pp. 487-492, 2013. https://doi.org/10.1109/ICCSCE.2013.6720014

[6] R. Ramadan and Y Widyani. "Game Development Life Cycle Guidelines". In 2013 International Conference on Advanced Computer Science and Information Systems (ICACSIS) - Proceeding, Pp. 95-100, 2013. https://doi.org/10.1109/ICACSIS.2013.6761558

[7] W. A. IJsselsteijn, Y. A. W. de Kort, and K Poels. The Game Experience Questionnaire. Eindhoven: Technische Universiteit Eindhoven. 2013.

[8] W. A. IJsselsteijn, Y. A. W. de Kort, K. Poels, A. Jurgelionis, and F. Bellotti. "Characterising and Measuring User Experiences in Digital Games," In the International Conference on Advances in Computer Entertainment Technology (ACE 2007) - Proceeding, Pp. 1-4, 2007.

[9] C. Heeter, Y. H. Lee, B. Magerko, and B. Medler. "Impacts of Forced Serious Gameplay on Vulnerable Subgroups," International Journal of Gaming and Computer-Mediated Simulations (IJGCMS), Vol. 3, No. 3, Pp. 34-53, 2011.

[10] R. Dubey, P. Agrawal, D. Pathak, T. Griffiths, and A. Efros. "Investigating Human Priors for Playing Video Games," The 35th International Conference on Machine Learning - Proceeding, Pp. 1349-1357.

(C) 2019 The Authors. Published by Universitas Muhammadiyah Malang

This is an open access article under the CC BY SA license. (https://creativecommons.org/licenses/by-sa/4.0/) 